KATARZYNA JADACH

Uniwersytet im. Adama Mickiewicza

w Poznaniu

\title{
PEDAGOGIKA PRAWA W POLSKIEJ SZKOLE
}

ABSTRACT. Jadach Katarzyna, Pedagogika prawa w polskiej szkole [Law Education in Polish Schools]. Studia Edukacyjne nr 34, 2015, Poznań 2015, pp. 19-44. Adam Mickiewicz University Press. ISBN 978-83-232-2896-7. ISSN 1233-6688. DOI: 10.14746/se.2015.34.2

The citizen's right to education guaranteed by the Polish Constitution includes the development of the student's civil attitude. To facilitate the development in the process of common education of mature, reliable, tolerant, open-minded individuals, aware of their rights and duties, it is necessary to transfer the knowledge and develop the authority enabling the youth to move within the existing community space. Beyond all doubt, community space is to a large extent determined by law. The article reflects on the mutual inspirations of pedagogy and law, the disciplines fundamental for the civil society.

Key words: law, law education, civil awareness, knowledge of law, justice system

W ramach gwarantowanego przez Konstytucję RP prawa obywatela do kształcenia przewidziane zostało przez ustawodawcę przekazywanie takich treści, które powinny przyczynić się do kształtowania u uczniów świadomych obywatelskich postaw. Aby w procesie powszechnej edukacji realna była realizacja bardzo poprawnego założenia uformowania jednostki dojrzałej, odpowiedzialnej, tolerancyjnej, otwartej, orientującej się w przysługujących jej prawach i ciążących nań obowiązkach, należy przekazywać młodym ludziom taką wiedzę i rozwijać takie kompetencje, które pozwolą im na pewne poruszanie się $\mathrm{w}$ istniejącej przestrzeni społecznej. Bez wątpienia, przestrzeń ta w znacznym stopniu determinowana jest literą prawa. W niniejszym artykule zaprezentowane zostaną wzajemne inspiracje dwóch podstawowych dla kondycji społeczeństwa obywatelskiego dziedzin: pedagogiki i prawaํ.

${ }^{1}$ Użyte w tytule sformułowanie „pedagogika prawa” ma konkretną semantykę wpisującą się w nurt polskiego prawoznawstwa, zainicjowanego przez Leona Petrażyckiego. Pewnym jej 
1. Edukacja to bardzo ważny obszar, na którym realizuje się władza wykonawcza (egzekutywa). Z samej swojej definicji władza ta ma służyć obywatelom i kierować (z łacińskiego ministrare) realizacją zadań publicznych². Doktryna prawa definiuje ją przez pryzmat administracji publicznej jako „strukturę obsadzoną ludźmi (określoną kadrą), która ma bezpośrednio realizować dobro wspólne, w sposób aktywny, planowy, stały, systematyczny i wyposażony we władztwo" ${ }^{3}$. Przywołana definicja zawiera trzy konstytutywne elementy: po pierwsze, wskazuje, iż składają się nań, używając języka ekonomii, określone zasoby ludzkie; po drugie, zasoby te zaopatrzone zostają w pewien zakres władztwa publicznego; po trzecie, władztwo to ma służyć realizacji „dobra wspólnego". Odnosząc powyższe elementy do zagadnienia edukacji, można odpowiednio skonstatować, że podmiot administrujący $\mathrm{w}$ tej dziedzinie wyraża się $\mathrm{w}$ przyjętym przez ustawodawcę terminie "organ prowadzący" szkołę bądź inną placówkę oświatową4. Celem skutecznego wdrożenia powierzonych mu zadań oświatowych podmiot publiczny dysponuje władztwem administracyjnym (imperium), czyli prawem egzekwowania przy użyciu przymusu państwowego swoich rozstrzygnięć z zakresu powierzonych mu zadań z pominięciem drogi sądowej5. Legitymację tej formy prymatu państwa nad jednostką wyraża następująca myśl: „(...) skoro państwo i jednostki samorządu terytorialnego, jako podmioty prawa publicznego, stwarzają obywatelom możliwość korzystania z usług edukacyjnych, świadczonych przez publiczne szkoły i placówki - to zarazem obywatele, korzystając $\mathrm{z}$ tych usług, mają prawny obowiązek podporządkowania się wydanym i obowiązującym $\mathrm{w}$ tych szkołach i placówkach regulacjom wewnętrznym $(. . .)^{\prime \prime}$.

Tak rozumiana podległość destynatariusza instytucji użyteczności publicznej aktom i poleceniom jej organów ma swoje prawne i aksjologiczne uzasadnienie. Podejmowane w obrębie danego zakładu administracyjnego

odpowiednikiem jest wdrażana obecnie w Niemczech przez Sigrun von Hasseln i jej zwolenników koncepcja Rechtspädagogik, rozumiana jako system edukacji i wychowania współczesnego społeczeństwa obywatelskiego odpowiadający wymaganiom współczesnego świata, patrz: D. Schmidt, Koncepcja niemieckiej pedagogiki prawa w ujęciu Sigrun von Hasseln, [w:] Prawo $i$ tad społeczny. Integralnokulturowa analiza zagadnienia racjonalności, red. J. Utrat-Milecki, Warszawa 2011, s. 439.

2 Administrowanie jest synonimem pomocy, służby, przewodnictwa, kierownictwa, prowadzenia, zarządzania lub organizowania dla osiągnięcia ustalonego celu, za: J. Zimmermann, Prawo administracyjne, Kraków 2006, s. 26.

${ }^{3}$ Def. za: Z. Cieślik, w: Z. Niewiadomski (red.), Prawo administracyjne, Warszawa 2011, s. 55.

${ }^{4}$ Art. 3 Ustawy o systemie oświaty z 07.09.1991 r., DzU nr 95, poz. 425 z późn. zm.

${ }^{5}$ E. Ochendowski, Prawo administracyjne. Część ogólna, Toruń 2009, s. 29-30.

${ }^{6}$ M. Pilich, Ustawa o systemie oświaty. Komentarz, Warszawa 2012, s. 536. 
(np. szkoły) działania służą bowiem wypełnieniu funkcji świadczącej poprzez zaspokajanie edukacyjnych potrzeb (dostarczanie dóbr w postaci wiedzy, umiejętności, kompetencji). Na podstawowym poziomie imperium państwa przyjmuje postać władztwa pedagogicznego (jako pewnej formy władztwa zakładowego) wykonywanego przez nauczyciela jako pracownika szkoły ${ }^{7}$. To on jest podmiotem bezpośrednio odpowiedzialnym za wykonywanie jej zadań opiekuńczych, dydaktycznych i wychowawczych, co ma swoje normatywne podstawy m.in. w art. 4 Ustawy o systemie oświaty („Nauczyciel w swoich działaniach dydaktycznych, wychowawczych i opiekuńczych ma obowiązek kierowania się dobrem uczniów, troską o ich zdrowie, postawę moralną i obywatelską z poszanowaniem godności osobistej ucznia"). Z drugiej strony, już pobieżna analiza celów, do jakich reprezentowana przez niego instytucja została powołana (szkoła jako miejsce, w którym krzewi się oświatę - dobro wspólne społeczeństwa, kształci i wychowuje $\mathrm{w}$ duchu poczucia odpowiedzialności, miłości ojczyzny oraz poszanowania dla polskiego dziedzictwa kulturowego, przy jednoczesnym otwarciu się na wartości kultur Europy i świata, zapewnia uczniowi warunki niezbędne do jego rozwoju, przygotowuje go do wypełniania obowiązków rodzinnych i obywatelskich w oparciu o zasady solidarności, demokracji, tolerancji, sprawiedliwości i wolności $\left.{ }^{8}\right)$, pozwala dokonać pewnej weryfikacji powszechnie panującego przekonania, że kompetentny do kształtowania przyszłych pokoleń jest wyłącznie nauczyciel. Nie jest tak i tak być nie powinno, zwłaszcza w kontekście zjawisk zachodzących we współczesnej zmiennej rzeczywistości, która dokonała bezpowrotnej dywersyfikacji źródeł dystrybucji wiedzy i umiejętności. Szkoła stała się jednym z wielu miejsc ich zdobywania, być może już nawet nie pierwszorzędnym. $Z$ pewnością jednak wciąż ważnym i posiadającym przewagę $\mathrm{w}$ postaci wspomnianego wcześniej atrybutu władztwa pedagogicznego (to, na ile umiejętnie z niego korzysta, stanowi odrębne zagadnienie). Oddanie tradycyjnie dzierżonej przez szkołę palmy pierwszeństwa w zakresie kształtowania młodych ludzi nie zwalnia jej z odpowiedzialności za efekt końcowy, czyli stan wiedzy, kultury i morale dorosłych obywateli.

2. W tym kontekście bardzo ciekawych informacji dostarcza materiał publikowany przez Centrum Badań Opinii Społecznej, obejmujący wyniki badań przeprowadzonych na reprezentatywnej grupie respondentów i dotyczący stosunku Polaków do prawa i osób będących przedstawicielami

\footnotetext{
7 Tamże, s. 51.

8 Preambuła do Ustawy o systemie oświaty z 07.09.1991 r., DzU nr 95, poz. 425 z późn. zm.
} 
szeroko pojętego wymiaru sprawiedliwości. Otóż, w komunikacie poświęconym przestrzeganiu prawa i funkcjonowaniu wymiaru sprawiedliwości w Polsce (komunikat z badań nr BS/5/2013) ${ }^{9}$ można przeczytać, że zdaniem ponad połowy badanych $(51 \%)$, większość Polaków często nie przestrzega litery prawa. Niestety, $\mathrm{w}$ badaniach nie podjęto zagadnienia przyczyn takiego stanu świadomości. Jednak $\mathrm{w}$ świetle zaobserwowanych przez ankieterów prawidłowości, wskazujących, iż opinia o nieprzestrzeganiu prawa jest szczególnie mocno artykułowana przez osoby o niskim statusie społecznym (uzyskujące miesięczny dochód per capita w kwocie od 501 zł do 1000 zł, pracowników usług i robotników niewykwalifikowanych) uprawniona wydaje się hipoteza, iż na stan świadomości prawnej, wyrażający się m.in. deklarowanym poczuciem przestrzegania prawa, wpływa m.in. wykształcenie oraz charakter wykonywanej pracy. Niepokojąca jest informacja, że większość badanych negatywny pogląd na temat funkcjonowania prawa (jego nieprzestrzeganie) opiera na doniesieniach medialnych. Dla 61\% (!) respondentów media stanowią jedyne źródło wiedzy na ten temat; $\mathrm{w} 16 \%$ przypadków są to opinie innych ludzi, a samodzielny pogląd o działaniu wymiaru sprawiedliwości oparty na osobistym doświadczeniu, związanym z załatwianiem różnego rodzaju spraw sądowych, deklaruje 17\% badanych. Dane te potwierdza deklaracja respondentów dotycząca kontaktów z sądem. Otóż, W ostatnich pięciu latach niewiele ponad jedna piąta badanych (22\%) miała osobisty kontakt $\mathrm{z}$ wymiarem sprawiedliwości. $\mathrm{W}$ tej grupie przeważali przedstawiciele kadry kierowniczej i specjaliści z wyższym wykształceniem, pracownicy średniego szczebla, osoby o najwyższych dochodach per capita. Prawidłowością była następująca zależność: im większa miejscowość zamieszkania respondentów oraz im wyższy poziom wykształcenia, tym kontakty z sądami były częstsze. Powyższe dane potwierdzają tezę, iż działalność wymiaru sprawiedliwości znajduje się w orbicie zainteresowań oraz możliwości przede wszystkim osób o wyższym statusie społecznym. Świadczyć to może o pewnego rodzaju ekskluzywności dobra, jakim jest formalne uporządkowanie swojej sytuacji prawnej - korzystają zeń obywatele posiadający z racji wykształcenia wyższą świadomość prawną, a także osoby o pewnych zasobach finansowych. Może to niepokoić w kontekście rodzaju spraw, jakie $\mathrm{w}$ tej grupie respondentów (korzystających $\mathrm{z}$ wymiaru sprawiedliwości) trafiają na tzw. wokandy sądów. Otóż, sprawy karne (tj. z zakresu prawa karnego i wykroczeń) stanowią w tym katalogu zaledwie 17\%, sprawy z zakresu prawa gospodarczego - $2 \%$, tzw. inne sprawy i okoliczności (np. wynikające z konieczności składania zeznań w charakterze świadka,

\footnotetext{
${ }^{9}$ Komunikat dostępny jest na stronie http://www.cbos.pl/PL/publikacje/raporty.php
} 
z wykonywanego zawodu itp.) - 16\%. W ponad 50\% przypadków przyczyną kontaktu z sądem były kwestie majątkowe (w tym m.in. sprawy spadkowe, sprawy o dochodzenie swoich roszczeń, o prawo do własności, zwrot mienia, odszkodowanie, sprawy dotyczące uregulowań prawnych nieruchomości) - 32\%, kwestie rodzinne i opiekuńcze (w tym m.in. sprawy rozwodowe, o separacje, sprawy alimentacyjne, sprawy o sprawowanie opieki nad dziećmi, o widywanie dzieci, uznanie ojcostwa, pozbawienie praw rodzicielskich) - $24 \%$ oraz sprawy z zakresu prawa pracy i ubezpieczeń społecznych - $13 \%$. Okazuje się więc, że pomimo tego, iż problemy rozpatrywane przez sądy mają charakter powszechny (np. kwestie dziedziczenia, sprawowania opieki nad dzieckiem, stosunku pracy), to jednak znaczna część obywateli (prawie 80\%) w ostatnich latach z możliwości uregulowania stosunków majątkowych i osobistych nie korzystała, a istotną tego przyczyną był brak wiedzy, gdzie i w jaki sposób należy to uczynić (z jakiej procedury skorzystać), ewentualnie brak stosownych środków finansowych do pokrycia tzw. kosztów sądowych czy fachowej obsługi prawnej.

Niezależnie od zaprezentowanej wyżej istotnej deprywacji Polaków w zakresie korzystania z usług wymiaru sprawiedliwości, może zastanawiać również stopień zadowolenia obywateli z działalności sądów oraz jego uwarunkowania. Otóż, w grupie osób deklarujących brak satysfakcji $(48 \%)$, wielu respondentów jako główną przyczynę takiego stanu rzeczy (obok przeważającego zarzutu przewlekłości postępowania) podało: niesatysfakcjonującą decyzję sądu lub wydanie niesprawiedliwego wyroku (14\%) oraz zbyt skomplikowane procedury związane z postępowaniem (8\%). Deklaracje te wskazują na wysoki stopień niezrozumienia treści orzeczeń sądowych, które jakkolwiek ulegając uprawomocnieniu formalnie kończą daną sprawę, ale w odczuciu zainteresowanych stron/uczestników nie rozwiązują konfliktu, nie pełnią funkcji stabilizowania stosunków społecznych i edukowania obywateli. Wręcz przeciwnie, dla wielu beneficjentów usług Temidy obraz sprawiedliwości pod wpływem przebytych, a niezrozumiałych procedur oraz niesatysfakcjonującego merytorycznego rozstrzygnięcia zaciemnia się i jeszcze bardziej zafałszowuje. Osobiste doświadczenie zamiast obalać nieuzasadniony zarzut skorumpowania i niekompetencji sędziów, dodatkowo go wzmacnia. Szukając wytłumaczenia dla subiektywnego poczucia niesprawiedliwości, obywatele zwracają się w kierunku przedstawicieli trzeciej władzy, upatrując tutaj źródła swoich krzywd. Stąd już tylko krok do przyjęcia postawy zniechęcenia i wrogości wyrażającej się podejmowanymi próbami podważania prawomocnych rozstrzygnięć jako przypadkowych i niesprawiedliwych. Nie trzeba chyba nikogo przekonywać, że w państwie prawa, gdzie naczelną konstytucyjną zasadą jest praworządność, rozumiana 
jako stan, w którym organy państwa działają na podstawie i w granicach prawa, a nakazy i zakazy prawne są w odczuciu społecznym oceniane dodatnio $^{10}$, takie nastroje społeczne mogą podważać jego fundamenty. Nie wspominając już o utopijności powszechnie hołubionej wizji społeczeństwa obywatelskiego. Społeczeństwo polskie nie będzie obywatelskie, dopóki nie będzie prawnie uświadomione.

Zaprezentowane dane wskazują jednoznacznie, że w życiu codziennym obywateli litera prawa (a zwłaszcza jej moc wyrażająca się w pozytywnym kształtowaniu stosunków międzyludzkich, w tym również konstruktywnym rozstrzyganiu zaistniałych konfliktów) przyjmuje kategorię "Innego". A tak być nie powinno. Nie po to ludzkość przez wieki rozwijała coraz bardziej zaawansowane formy uwspólnotowienia, aby jedna z podstawowych więzi ją spajających i porządkujących jej funkcjonowanie w czytelnych, precyzyjnych granicach, była obecnie derogowana. Litera prawa stanowi podwaliny nowożytnej cywilizacji, dorobek wielu pokoleń „mędrców i pospólstwa", nić spajającą monteskiuszowską strukturę, na której opierają się wszystkie współczesne cywilizowane państwa. Nie można jej traktować jak "obcego", a działalności systemu ją wdrażającego jako przypadkowego lub skorumpowanego. Taka świadomość obywatelska wymaga przewartościowania poprzez podjęcie pracy u podstaw, czyli obalania szkodliwych mitów, systematyczne uświadamianie młodych pokoleń, pokazywanie przykładów... słowem edukowanie.

3. Skuteczne podjęcie inicjatywy prawnej edukacji społeczeństwa wymaga rozprawienia się z mitem - zawłaszczania kompetencji. W proponowanej formule nie ma miejsca na taki oto stan rzeczy, gdzie „prawo jest dla prawnika, a edukacja dla pedagoga". Prawo może i powinno uczyć, jak postępować w relacjach międzyludzkich; edukacja może i powinna wychowywać praworządnego obywatela. Wiara $\mathrm{w}$ to, iż dziedziny nauki zupełnie od siebie niezależne, posiadające piękny dorobek, własną terminologię i zasłużonych przedstawicieli, podejmą wspólny trud kształtowania świadomego, a co za tym idzie - odpowiedzialnego człowieka, ma swoje aksjologiczne uzasadnienie i zaangażowanych wyznawców. Dostrzegając trud tych, którzy w swojej codziennej pedagogicznej pracy uczą młodych ludzi, jak poruszać się w złożonym świecie i odkrywają przed nimi funkcjonalne powiązania wszystkich jego elementów, warto pochylić się nad inicjatywami, które $\mathrm{w}$ ostatnich miesiącach czy latach rozwijają się $\mathrm{w}$ środowisku prawniczym, a których podstawowym wspólnym celem jest podwyższanie świadomości prawnej obywateli. Można tu wymienić m.in.: organizowany od szeregu lat

10 A. Redelbach, Wstęp do prawoznawstwa, Toruń 2002, s. 250-251. 
tydzień pomocy dla ofiar przestępstw, darmowo udzielane przez prawników porady prawne, bezpłatne linki tematyczne na stronach internetowych, pomoc $\mathrm{w}$ znalezieniu prawnika lub kancelarii, ogólnodostępne broszury informacyjne itp. Do refleksji skłaniają wypowiedzi zaangażowanych prawników: „(...) człowiek, który nie ma podstawowej wiedzy prawniczej, nie rozumie rzeczywistości, która go otacza, i nie jest w stanie poradzić sobie w różnych sytuacjach, bowiem żyjemy w dobie wszechobecności prawa"11 (Łukasz Bojarski, Helsińska Fundacja Praw Człowieka); „Prawo to nie jest jakaś abstrakcja, lecz podstawa naszego życia społecznego. Domaganie się rozpowszechnienia znajomości prawa nie jest fanaberią, ale działaniem $\mathrm{w}$ dobrze pojętym interesie społecznym. $\mathrm{W}$ tym miejscu rodzi się pytanie jak to robić? Bardzo łatwo - prawa trzeba po prostu uczyć!"12 (Krystyna Babiak, dziekan Okręgowej Izby Radców Prawnych w Poznaniu). Zainteresowanie przedstawicieli środowisk prawniczych edukowaniem młodych obywateli wynika m.in. z pewnych, poczynionych w okolicznościach obsługi prawnej zgłaszających się doń klientów, obserwacji. Często zainteresowane pomocą prawną osoby pojawiają się $\mathrm{w}$ kancelarii $\mathrm{w}$ momencie, kiedy pewne ruchy procesowe - z uwagi na upływ wiążących strony terminów, ewentualnie stopień zaawansowania sprawy toczącej się już przed sądem są niemożliwe, co powoduje niezadowolenie niezorientowanych $\mathrm{w}$ przepisach prawa klientów i rzutuje na sposób postrzegania mecenasa oraz niską ocenę skuteczności jego pracy. Obserwacje te potwierdzają wyniki badań CBOS. W komunikacie „Kontakty z prawem, ocena instytucji prawnych i poczucie bezpieczeństwa Polaków"13 (nr BS/42/2008) wyartykułowany został następujący wniosek: "Zadowolenie z nawiązywanych kontaktów z przedstawicielami zawodów prawniczych jest na ogół tym większe, im te kontakty są częstsze"14. Oznacza to, że osoby świadome, na czym polega pomoc prawna, gdzie, a przede wszystkim kiedy należy jej szukać, otrzymują skuteczne profesjonalne wsparcie, co rzutuje na wyższy stopień zadowolenia z usługi, w porównaniu z osobami, dla których kontakt z prawnikiem jest incydentalny i którzy nie są świadomi, czego mogą i powinni oczekiwać od prawnika w danym stanie okoliczności faktycznych.

Innym rodzajem motywacji, napędzającym prawników do działania na rzecz edukacji, jest bez wątpienia chęć zapoznania obywateli z możliwo-

11 Wypowiedź dostępna jest na stronie internetowej www.perspektywy.pl/index.php? option=com_content\&task $=$ view\&id $=2537$.

12 Tamże.

${ }_{13}$ Dane dostępne na stronie internetowej: http://www.cbos.pl/PL/publikacje/raporty. php.

${ }_{14}$ Komunikat CBOS: Kontakty z prawem, ocena instytucji prawnych i poczucie bezpieczeństwa Polaków (nr BS/42/2008), s. 2, http://www.cbos.pl/PL/publikacje/raporty.php. 
ściami, jakie daje prawo i potencjalnymi korzyściami, które można osiągnąć przy jego osobistej znajomości, ewentualnie przy skorzystaniu z tzw. porady prawnej bądź przy zaangażowaniu profesjonalnego pełnomocnika. Jak wynika z przywołanych wcześniej badań CBOS (komunikat nr BS/42/2008), w obecnym stanie rzeczy większość Polaków korzysta z usług prawniczych o charakterze czynności notarialnych $(21,9 \%)$; zdecydowanie rzadziej badani zwracają się do radcy prawnego $(7,6 \%)$ czy adwokata $(7,4 \%)$. Sąd w tym zestawieniu plasuje się na drugim miejscu $(21,5 \%)$, co może oznaczać, iż Polacy nie mają nawyku korzystania z pomocy prawnej, sami podejmują trud działania w sądzie, a usługa prawnicza, na którą najczęściej się decydują, to z uwagi na formalne wymogi (zachowania przy podejmowaniu czynności prawnej specjalnej formy aktu notarialnego) sporządzenie przez notariusza stosownego aktu. Na tym polu pozostaje więc wiele do zrobienia, tym bardziej że tzw. rynek prawniczy jest coraz większy i bardziej konkurencyjny, a popyt na usługi prawnicze ciągle niezadowalający $\mathrm{w}$ stosunku do zwiększającego się podażu.

W przypadku środowiska sędziowskiego zaangażowanie $\mathrm{w}$ edukację prawną ma nieco odmienne uzasadnienie. Przede wszystkim, sędziowie dostrzegają konieczność przewartościowania wizerunku Temidy, jaki $\mathrm{w}$ społeczeństwie polskim występuje ${ }^{15}$. Nie jest on niestety pozytywny, o czym świadczą wyniki przywołanych wyżej badań CBOS ze stycznia 2013 r. (komunikat nr BS/5/2013). Wynika z nich nie tylko wysoki wskaźnik niezadowolenia z pracy sądu (48\%), ale co szczególnie może niepokoić i zastanawiać, wśród przyczyn tego niezadowolenia respondenci podawali $\mathrm{w}$ przeważającej liczbie okoliczności powiązane z osobą sędziego, ewentualnie z praktyką orzeczniczą, takie jak: orzekanie zbyt niskich kar, korupcję, niekompetencję, złe traktowanie obywateli, naruszanie przepisów w stosowaniu procedur czy wydawanie wyroków na podstawie niewystarczającego materiału dowodowego ${ }^{16}$. Deklarowany stosunek do sędziów jest w większości ambiwalentny (51\%), natomiast wśród jednoznacznych opinii przeważają negatywne (23\%). Znamienne jest również, że w przeważającej liczbie badani negują oparcie wymiaru sprawiedliwości na fundamentalnej zasadzie niezawisłości sędziowskiej, twierdząc, że nie stanowi ona reguły i „różnie z nią bywa”; o nieuleganiu przez sędziów żadnym zewnętrznym naciskom przekonanych jest jedynie $22 \%$ respondentów. Obraz dopełnia porównanie stosunku Polaków do sądownictwa w kraju oraz instancji o wymiarze międzynarodowym - blisko $3 / 4$ badanych $(72 \%)$ przyznaje, iż większym zaufaniem darzy Europejski Trybunał Praw Człowieka w Stras-

15 J. Machura-Szczęsna, Sędzia i kaganek oświaty, Na Wokandzie, 2012, 1, 11.

${ }^{16}$ Komunikat CBOS: O przestrzeganiu prawa i funkcjonowaniu wymiaru sprawiedliwości w Polsce (nr BS/5/2013), s. 20, http://www.cbos.pl/PL/publikacje/raporty.php. 
burgu aniżeli polskie sądy. W tym kontekście nie powinny dziwić głosy przedstawicieli trzeciej władzy nawołujące do podjęcia wysiłku w kierunku zmiany sposobu ich społecznego postrzegania ${ }^{17}$.

4. Niewątpliwie przysłużyć się temu może aktualnie podejmowana na terenie województwa wielkopolskiego praca edukacyjna z młodzieżą szkolną. Zainicjowany w ramach współpracy międzyresortowej (MEN i MS) i międzysektorowej (wskazane ministerstwa, wielkopolskie kuratorium oświaty, poszczególne szkoły, sądy w okręgu Sądu Apelacyjnego w Poznaniu, stowarzyszenia), wsparty doświadczeniem przedstawicieli korporacji prawniczych (przede wszystkim radców prawnych z Okręgowej Izby Radców Prawnych w Poznaniu) program ${ }^{18}$ przybliżania młodym obywatelom meandrów prawa ma szansę odnieść sukces. Biorąc pod uwagę korzyści, jakie z jego skutecznej realizacji można będzie odnieść, należy żywić nadzieję, iż współpraca tak szerokiego gremium przedstawicieli różnych środowisk zatroskanych o poziom praktycznej wiedzy obywateli w zakresie możliwości, jakie daje im prawo, będzie owocna i trwała. Warto przy tej okazji zauważyć, że zainaugurowany program wychodzi naprzeciw nie tylko zapotrzebowaniu korporacji prawniczych i wymiaru sprawiedliwości na świadomego beneficjenta świadczeń, ale przede wszystkim szkołom, objętym od kilku lat reformą edukacji $w$ obszarze realizacji podstaw programowych na poziomie kształcenia ogólnego ${ }^{19}$.

Wprowadzone w Rozporządzeniach MEN z 23 grudnia 2008 r. w sprawie podstawy programowej wychowania przedszkolnego oraz kształcenia ogólnego w poszczególnych typach szkół oraz z 27 sierpnia 2012 r. w sprawie podstawy programowej wychowania przedszkolnego oraz kształcenia

17 Oto ważny głos przedstawiciela środowiska sędziowskiego: „(...) w związku ze zmianami cywilizacyjnymi (...) współczesny sędzia musi uczestniczyć także $\mathrm{w}$ przestrzeni publicznej. Oczywiście nie powinien wypowiadać się w kwestiach politycznych (...). Natomiast, jeżeli chodzi o podstawowe wartości, to jak najbardziej powinien się wypowiadać. Podstawowe wartości, to takie wartości, jak konieczność wspierania, ochrony godności człowieka i wynikające z tego kwestie. Sędzia powinien się przeciwstawiać uprzedmiotowianiu ludzi, (...) powinien odczytywać funkcjonujące $w$ społeczeństwie wartości i wspierać je w swoim orzecznictwie, tj. poprzez wymierzanie sprawiedliwości", Sady to moje życie - wywiad Krystiana Markiewicza i Bartłomieja Przymusińskiego z sędzią Stanisławem Dąbrowskim, Pierwszym Prezesem Sądu Najwyższego, Iustitia, 2012, 1, s. 7-8.

18 Dane na temat edukacji prawnej dostępne są na stronie: www.poznan.sa.gov.pl.

19 Wdrożeniu tzw. reformy programowej służy: uchylone 1 września 2012 r. Rozporządzenie MEN z 23 grudnia 2008 r. w sprawie podstawy programowej wychowania przedszkolnego oraz kształcenia ogólnego $\mathrm{w}$ poszczególnych typach szkół oraz, obecnie obowiązujące, Rozporządzenie MEN z 27 sierpnia 2012 r. w sprawie podstawy programowej wychowania przedszkolnego oraz kształcenia ogólnego w poszczególnych typach szkół. 
ogólnego w poszczególnych typach szkół20 zmiany dotyczyły m.in. programów realizowanych na tzw. 3. i 4. szczeblu edukacji (gimnazja oraz szkoły ponadgimnazjalne). Otóż, w opracowanym przez MEN komentarzu do nowelizacji $^{21}$ zawarto następujące założenia, determinujące konieczność uzupełnienia oferty edukacyjnej dla młodzieży szkolnej $\mathrm{w}$ ramach przedmiotu Wiedza o społeczeństwie: „Wiedza o społeczeństwie to przedmiot, który łączy przekazywanie wiedzy z kształtowaniem umiejętności i postaw obywatelskich" 22; „Podstawa programowa kształcenia ogólnego dla gimnazjów i szkół ponadgimnazjalnych zakłada, że szkoła powinna kształtować u uczniów postawy warunkujące sprawne i odpowiedzialne funkcjonowanie we współczesnym świecie, a przy tym sprzyjające ich rozwojowi indywidualnemu i społecznemu"23. Rozwijanie wśród młodych ludzi postaw i kompetencji obywatelskich twórcy reformy programowej słusznie upatrują m.in. $\mathrm{w}$ takim konstruowaniu programu szkolnego, który da im szansę na oswojenie się z literą prawa. Służyć temu ma "praktyczna edukacja prawna, zdobywanie umiejętności wyszukiwania i rozumienia przepisów oraz podstawowych procedur $\mathrm{w}$ urzędach, sądach i innych instytucjach życia publicznego"24. W opinii MEN edukacja prawna w zakresie podstawowym (III i IV etap) powinna koncentrować się na rozwijaniu kompetencji obywatelskich i społecznych zawartych w wymaganiach ogólnych, co wiąże się z przyswojeniem przez uczniów wiedzy i umiejętności obcowania z prawem, zwłaszcza stosowania przepisów w różnych sytuacjach życiowych. Uczniowie powinni „oswoić się z językiem urzędowym, aby rozumieć dotyczące ich dokumenty i umieć sporządzać pisma urzędowe. Przyswojenie fundamentalnej wiedzy o instytucjach publicznych i zasadach ich działania ma dać uczniom umiejętność skutecznego poruszania się w nich z zachowaniem kryteriów legalności. Przygotowuje to ich także do samoorganizacji i współpracy w kontaktach z urzędami, policją, pracodawcami i innymi instytucjami życia publicznego" 25 . Przyjęte przez MEN założenia w perspektywie przywołanych badań CBOS wydają się słuszne, a ich stopniowe wdrażanie konieczne. Zawsze jednak pozostaje pytanie o sposób implikacji, w szczególności zakres poruszanych zagadnień (stopień trudności) oraz przygotowanie nauczycieli do rzetelnego przekazywania tych treści.

20 Tamże, DzU z 2012 r., poz. 977.

${ }^{21}$ Podstawa programowa z komentarzem, tom 4: Edukacja historyczna i obywatelska w szkole podstawowej, gimnazjum i liceum. Historia i spoteczeństwo, historia, wiedza o społeczeństwie, podstawy przedsiębiorczości, ekonomia w praktyce, wychowanie do życia w rodzinie, etyka, filozofia, www.bc.ore.edu.pl.

22 Tamże, s. 112.

23 Tamże.

${ }^{24}$ Tamże, s. 114.

25 Tamże, s. 121. 


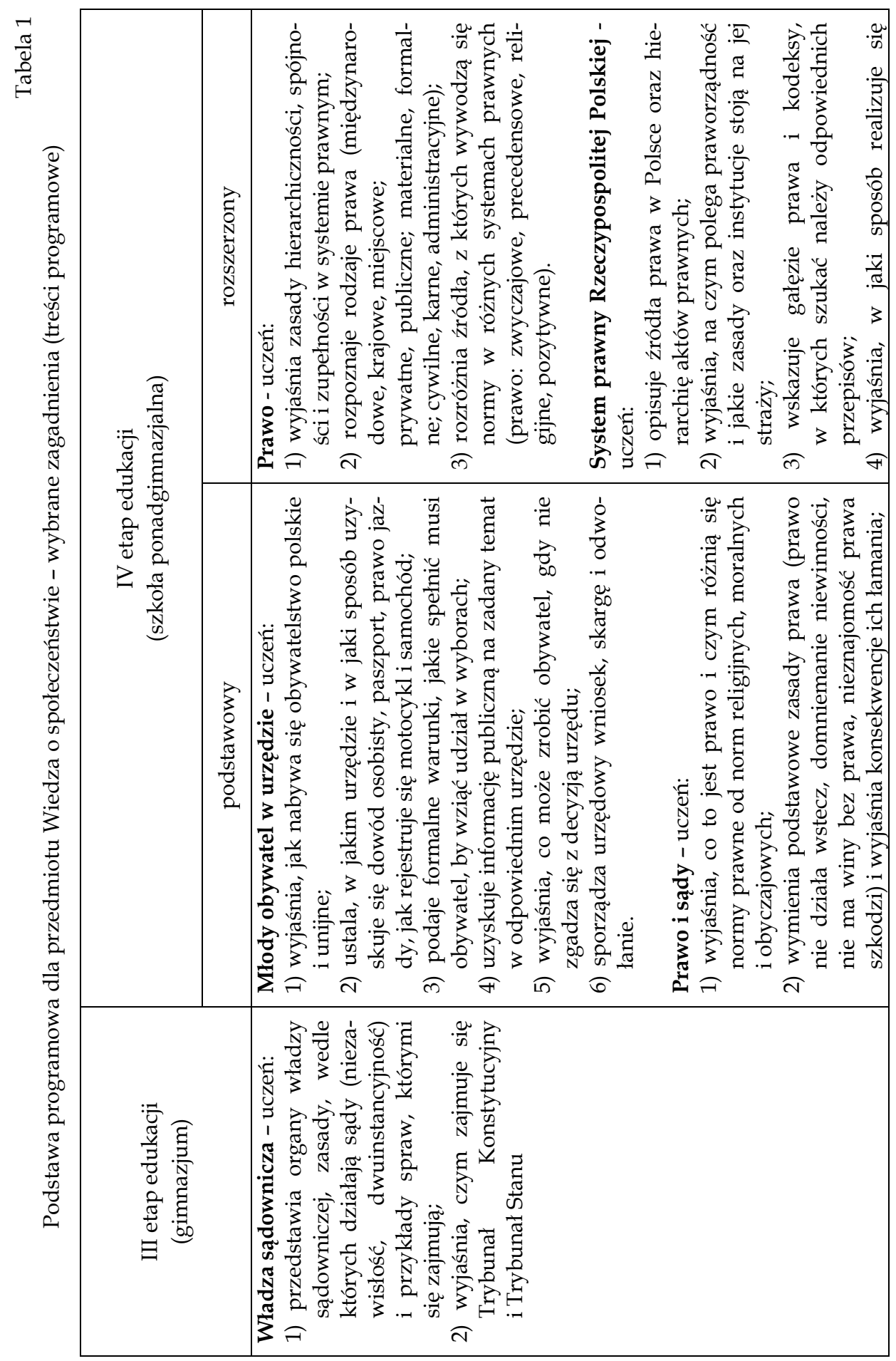




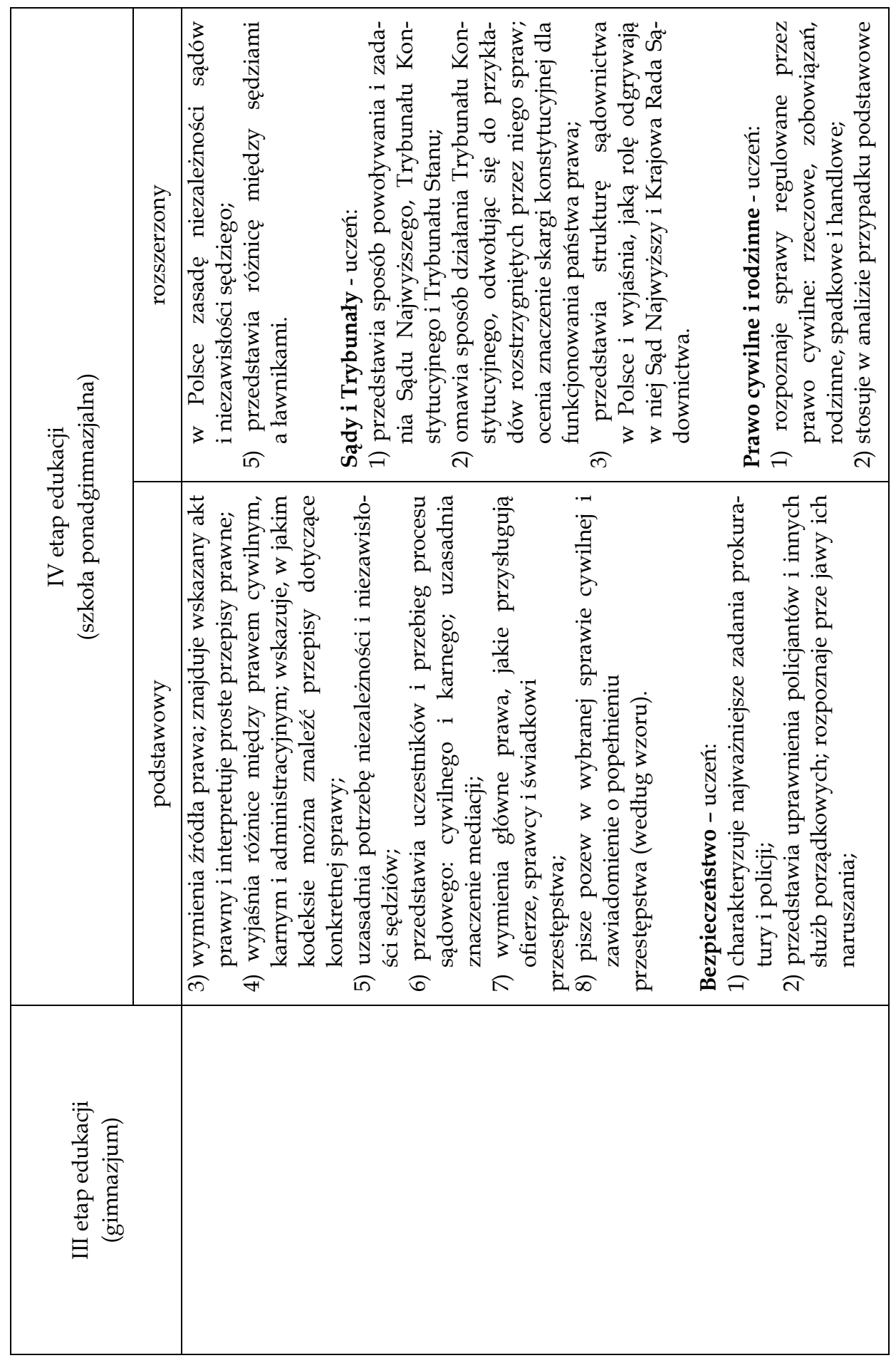




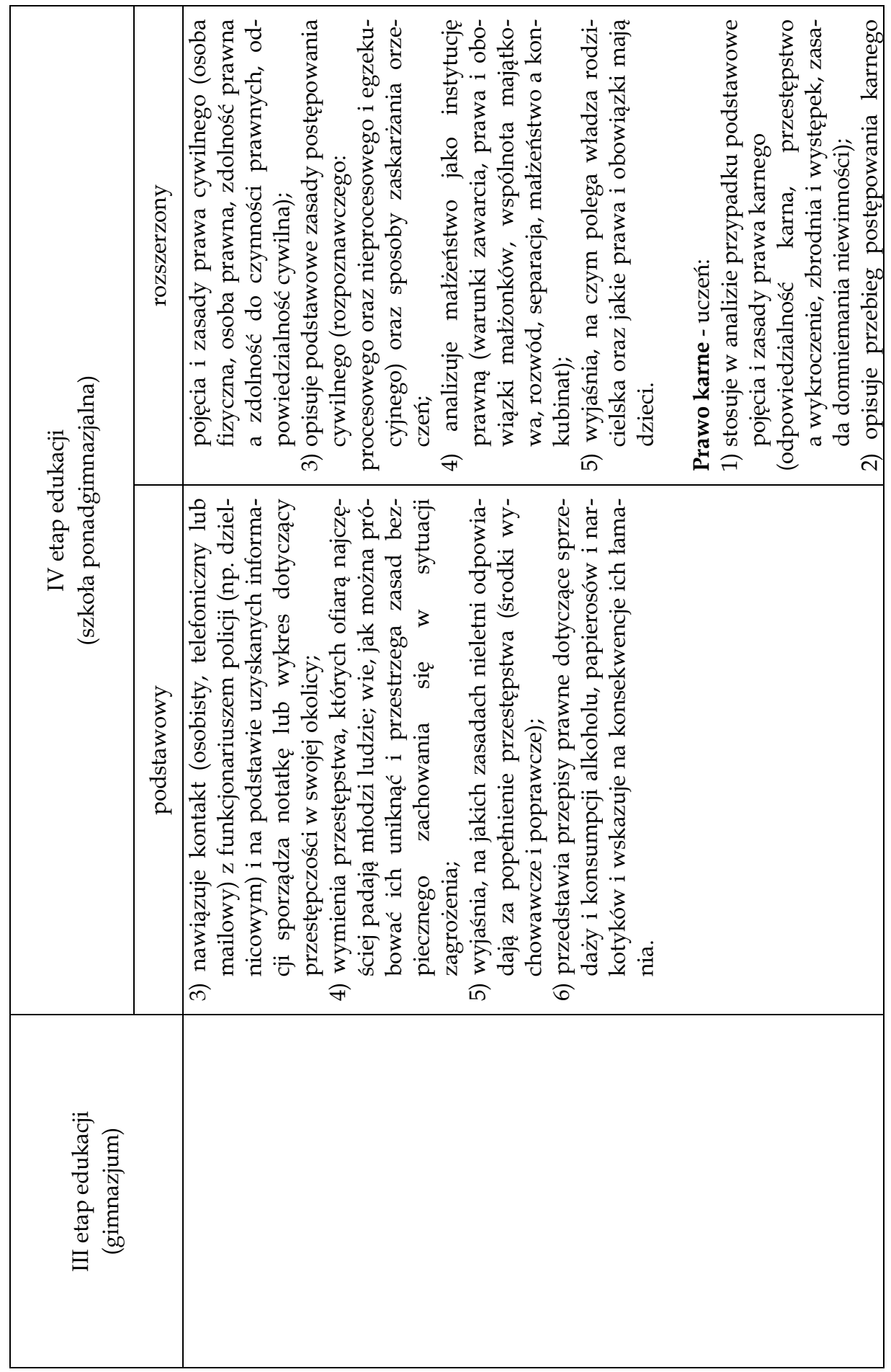




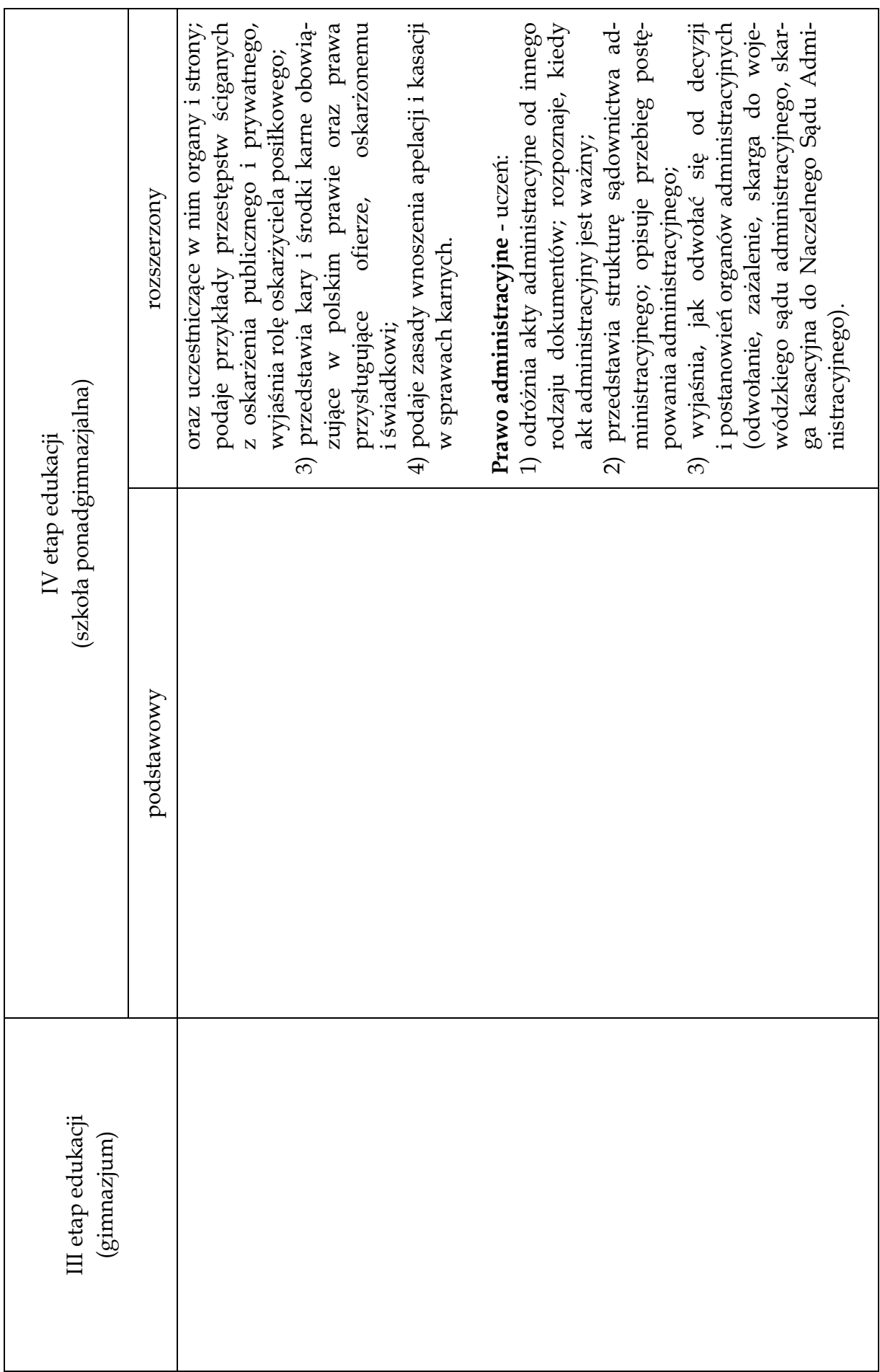




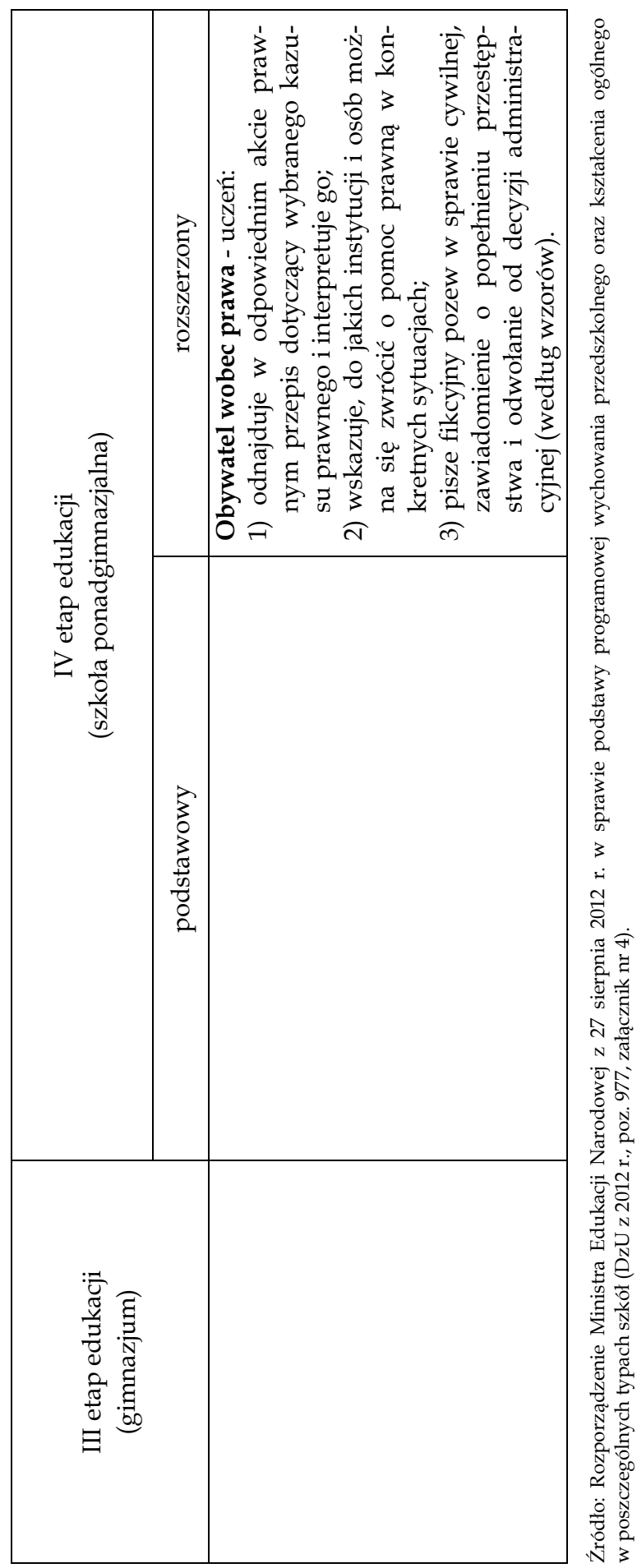


5. W opracowanym przez Ministerstwo Edukacji Narodowej komentarzu do przedmiotu Edukacja historyczna i obywatelska w szkole podstawowej, gimnazjum i liceum przeczytać można: „Minister Edukacji określa zakres celów oraz treści ksztatcenia w rozporządzeniu o podstawie programowej ksztatcenia ogólnego. Podstawa programowa precyzyjnie określa, czego szkoła jest zobowiązana nauczyć ucznia o przeciętnych uzdolnieniach na każdym etapie ksztatcenia, zachęcając jednocześnie do wzbogacania i pogłębiania treści nauczania. Autorzy podstawy dołożyli wszelkich starań, by zdefiniowany w niej zakres treści byt możliwy do opanowania przez takiego ucznia"26. Opracowany przez twórców reformy programowej zestaw celów, a przede wszystkim treści kształcenia w obszarze wiedza o społeczeństwie na IV etapie obowiązkowej edukacji zdecydowanie nie spełnia założenia zdefiniowania zakresu materiału w taki sposób, aby przeciętny uczeń mógł go opanować. Wystarczy pochylić się nad następującymi zakładanymi do realizacji na poziomie podstawowym szkoły ponadgimnazjalnej treściami: „wyjaśnianie różnic pomiędzy prawem cywilnym, administracyjnym i karnym", "przedstawienie przebiegu postępowania sądowego cywilnego i karnego", "pisanie pozwu w wybranej sprawie cywilnej". Pomijając już kwestie pewnych zasadniczych błędów merytorycznych (w przypadku gdy mowa o osobie nieletniej, wobec której zastosowano środek wychowawczy/poprawczy nie jest w zasadzie uzasadnione posługiwanie się sformułowaniem popełnienia przez nieletniego przestępstwa; w sytuacji zakładanego prawdopodobieństwa bycia świadkiem przestępstwa, podstawowa informacja, którą należałoby uczniowi przekazać, to obowiązki, jakie wówczas na takiej osobie spoczywają) i nieuzasadnionych pominięć, jakie pojawiły się $\mathrm{w}$ przedmiotowej podstawie programowej (dlaczego przy prezentacji poszczególnych gałęzi prawa zaniechano zapoznania młodych ludzi z tematyką prawa pracy, w sytuacji gdy wielu uczniów podejmuje tymczasowe zatrudnienie, padając niestety ofiarami nadużyć ze strony pracodawcy lub zleceniodawcy; dlaczego w obszarze prawa cywilnego nie uwzględniono problematyki własności intelektualnej oraz notorycznych, sprzecznych $\mathrm{z}$ prawem, a niestety często podejmowanych przez uczniów praktyk naruszania praw autorskich, a już zupełnie niezrozumiałe jest przemilczenie zagadnień prawnorodzinnych), w głowie osób nawet pobieżnie obeznanych $\mathrm{z}$ prawem rodzi się pytanie o racjonalność tak szeroko zakrojonej problematyki i intelektualne możliwości bardzo młodych przecież osób, ale nie tylko ich. Jeżeli przyjąć optymistyczne założenie, że przeciętny polski uczeń liceum na skutek ambitnej reformy programowej

26 Z. Marciniak, O potrzebie reformy programowej kształcenia ogólnego, [w:] Tom 4, Edukacja historyczna i obywatelska w szkole podstawowej, gimnazjum i liceum, Biblioteka Cyfrowa ORE, s. 10, www.bc.ore.edu.pl. 
będzie potrafił sprawnie posługiwać się kodeksami i rozwiązywać konkretne kazusy, to przeszkolenie tego typu powinien mu zapewnić fachowiec prawnik, który nie tylko będzie w stanie wskazać, jakie przepisy obowiązują, ale również, jak na ich podstawie działa procedura cywilna, karna, czy administracyjna (w IV etapie na poziomie rozszerzonym dla przedmiotu Wiedza o społeczeństwie MEN zawarto $w$ języku wymagań następujące treści: „uczeń opisuje podstawowe zasady postępowania cywilnego rozpoznawczego: procesowego oraz nieprocesowego i egzekucyjnego oraz sposoby zaskarżania orzeczeń"; "uczeń opisuje przebieg postępowania karnego, podaje zasady wnoszenia apelacji i kasacji w sprawach karnych”; „uczeń opisuje przebieg postępowania administracyjnego oraz wyjaśnia, jak odwołać się od decyzji i postanowień organów administracyjnych"). Hamując nieco prześmiewczy ton, jaki lektura podstawy programowej stymuluje, należy zastanowić się nad sensem wprowadzania rozwiązań, które w realiach polskich szkół nie mają szans na wdrożenie. Błędne jest przyjęte przez twórców reformy założenie, aby jak najbardziej pożądany cel (osiągnięcie stanu, w którym polski uczeń będzie miał znajomość zasad i procedur demokracji, podstaw ustroju RP oraz rozpoznawał prawne aspekty codziennych problemów życiowych) realizować poprzez wdrażanie na szczeblu edukacji ogólnej poszczególnych przedmiotów z zakresu studiów prawniczych. Za nieporozumienie należy również uznać stawianie nauczycieli prowadzących lekcje $\mathrm{z}$ Wiedzy o społeczeństwie ${ }^{27} \mathrm{w}$ roli biegłych $\mathrm{w}$ prawie, a najlepiej praktykujących prawników, którzy na dodatkowe pytania ucznia zainteresowanego omawianym $\mathrm{w}$ trakcie zajęć kazusem udzielą wyczerpującej i prawidłowej (!) odpowiedzi. Kreowanie na etapie legislacyjnym tego typu potencjalnych sytuacji świadczy albo o złej wierze (przykrywaniu pod

27 §2.1. Rozporządzenia Ministra Edukacji Narodowej z 12 marca 2009 r. w sprawie szczegółowych kwalifikacji wymaganych od nauczycieli oraz określenia szkół i wypadków, w których można zatrudnić nauczycieli niemających wyższego wykształcenia lub ukończonego zakładu kształcenia nauczycieli (DzU nr 50, poz. 400 ze zm.): „Kwalifikacje do zajmowania stanowiska nauczyciela $\mathrm{w}$ zakładach kształcenia nauczycieli, placówkach doskonalenia nauczycieli, poradniach psychologiczno-pedagogicznych, w tym poradniach specjalistycznych, bibliotekach pedagogicznych, kolegiach pracowników służb społecznych, liceach ogólnokształcących, liceach profilowanych, technikach, uzupełniających liceach ogólnokształcących, technikach uzupełniających i szkołach policealnych, z zastrzeżeniem $\S 11$ ust. 1 i 2, §12-14, 1622 i 24, posiada osoba, która ukończyła: 1) Studia magisterskie na kierunku (specjalności) zgodnym $\mathrm{z}$ nauczanym przedmiotem lub prowadzonymi zajęciami oraz posiada przygotowanie pedagogiczne lub 2) Studia magisterskie na kierunku, którego zakres określony w standardzie kształcenia danego kierunku studiów w grupie treści podstawowych i kierunkowych obejmuje treści nauczanego przedmiotu lub prowadzonych zajęć, oraz posiada przygotowanie pedagogiczne, lub 3) Studia magisterskie na kierunku (specjalności) innym niż wymieniony w pkt 1 i 2 i studia podyplomowe w zakresie nauczanego przedmiotu lub prowadzonych zajęć oraz ma przygotowanie pedagogiczne. 
płaszczykiem nośnych haseł kształtowania świadomego i aktywnego obywatela braku pomysłów na konstruktywną, realną edukację i przerzucania ciężaru reformy na dyrekcję i nauczycieli), albo o braku wiedzy o specyfice niezwykle przecież bogatego systemu prawa (innymi słowy - o projektowaniu nowej „jakości” przez osoby niekompetentne). Ponieważ sama potrzeba, jak to już wcześniej zostało podkreślone, podwyższania świadomości prawnej społeczeństwa istnieje, warto wsłuchać się w głosy fachowców. Poniżej zaprezentowano treści, jakie $w$ ramach poszczególnych gałęzi prawa zostały zaproponowane do przybliżenia młodzieży przez członków zespołów tematycznych, pracujących w ramach II Kongresu Prawników Wielkopolski, jaki odbył się 19.11.2012 r. w Poznaniu28.

Tabela 2

Zespoły tematyczne i ich propozycje - wybrane zagadnienia

\begin{tabular}{|c|c|c|}
\hline \multirow{2}{*}{$\begin{array}{c}\text { Zespoły } \\
\text { tematyczne }\end{array}$} & \multicolumn{2}{|r|}{ Propozycje } \\
\hline & Cele/sposoby realizacji & Zagadnienia \\
\hline $\begin{array}{l}\text { Zespół Prawa } \\
\text { Konstytucyj- } \\
\text { nego }\end{array}$ & $\begin{array}{l}\text { - podstawowa orientacja } \\
\text { w zakresie prawa ustro- } \\
\text { jowego }\end{array}$ & $\begin{array}{l}\text { Pojęcia: państwo, suwerenność, teryto- } \\
\text { rium, obywatelstwo, mniejszości naro- } \\
\text { dowe, ustrój język urzędowy, barwy } \\
\text { RP, godło, hymn, wolności, prawa } \\
\text { i obowiązki człowieka i obywatela, } \\
\text { źródła prawa - Konstytucja, ustawy, } \\
\text { ratyfikowane umowy międzynarodo- } \\
\text { we, rozporządzenia, akty prawa miej- } \\
\text { scowego, władza ustawodawcza, pre- } \\
\text { zydent RP, Rada Ministrów } \\
\text { i administracja rządowa, samorząd } \\
\text { terytorialny, sądy i Krajowa Rada Są- } \\
\text { downictwa, Trybunał Konstytucyjny } \\
\text { i Trybunał Stanu, Najwyższa Izba Kon- } \\
\text { troli, Rzecznik Praw Obywatelskich, } \\
\text { Rzecznik Praw Dziecka, finanse pu- } \\
\text { bliczne, stan nadzwyczajny, stan wo- } \\
\text { jenny, stan wyjątkowy, stan klęski } \\
\text { żywiołowej, niektóre formy współpracy } \\
\text { międzynarodowej państwa. }\end{array}$ \\
\hline $\begin{array}{l}\text { Zespół Prawa } \\
\text { Karnego }\end{array}$ & $\begin{array}{l}\text { - broszura edukacyjna dla } \\
\text { młodzieży zawierająca } \\
\text { proste wyjaśnienia } \mathrm{w} \\
\text { postaci odpowiedzi na } \\
\text { pytania }\end{array}$ & $\begin{array}{l}\text { 1. Perspektywa "sprawcy" deliktu } \\
\text { penalnego: Co to jest przestęp- } \\
\text { stwo/wykroczenie? Kiedy popeł- } \\
\text { niam przestępstwo/wykroczenie? } \\
\text { Jaka kara grozi mi za popełnienie }\end{array}$ \\
\hline
\end{tabular}

${ }^{28}$ Informacje na temat Kongresu dostępne są na stronie internetowej: www.poznan. sa.gov.pl. 


\begin{tabular}{|c|c|c|}
\hline \multirow{2}{*}{$\begin{array}{c}\text { Zespoły } \\
\text { tematyczne }\end{array}$} & \multicolumn{2}{|r|}{ Propozycje } \\
\hline & Cele/sposoby realizacji & Zagadnienia \\
\hline & & 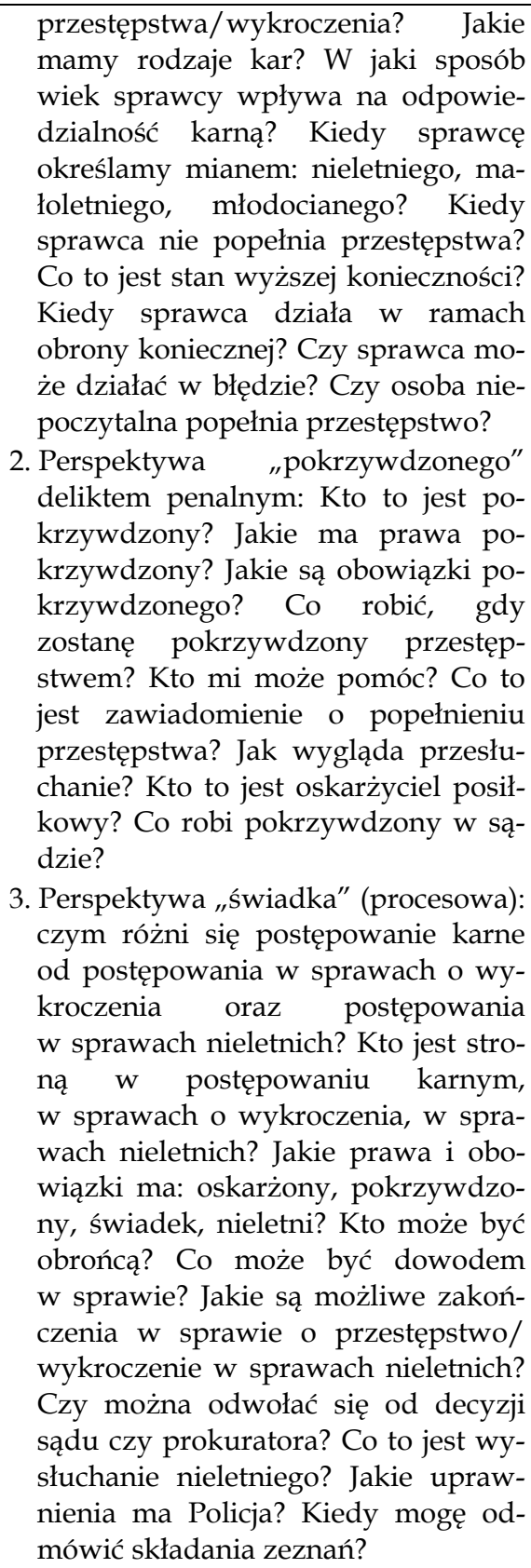 \\
\hline $\begin{array}{l}\text { Zespół Prawa } \\
\text { Cywilnego }\end{array}$ & $\begin{array}{l}\text { - praca z wykorzystaniem } \\
\text { konkretnych stanów fak- }\end{array}$ & $\begin{array}{l}\text { Pojęcia: czyny niedozwolone, odszko- } \\
\text { dowanie, zadośćuczynienie, ustalenie }\end{array}$ \\
\hline
\end{tabular}




\begin{tabular}{|c|c|c|}
\hline \multirow{2}{*}{$\begin{array}{c}\text { Zespoły } \\
\text { tematyczne }\end{array}$} & \multicolumn{2}{|r|}{ Propozycje } \\
\hline & Cele/sposoby realizacji & Zagadnienia \\
\hline & tycznych (kazusów) & $\begin{array}{l}\text { odpowiedzialności, odpowiedzialność } \\
\text { małoletniego, odpowiedzialność rodzi- } \\
\text { ców, wypadek, przyczynienie się po- } \\
\text { szkodowanego do powstania szkody, } \\
\text { związek przyczynowy, naprawienie } \\
\text { szkody, zarząd majątkiem dziecka, } \\
\text { odpowiedzialność dziecka za długi } \\
\text { rodziców, przyjęcie/odrzucenie spad- } \\
\text { ku, przyjęcie spadku wprost i z dobro- } \\
\text { dziejstwem inwentarza, ustanowienie } \\
\text { opiekuna, zdolność do czynności } \\
\text { prawnych, zawieranie umów przez } \\
\text { Internet, kara umowna, regulamin } \\
\text { umieszczony na stronie internetowej, } \\
\text { wzorce umów, odstąpienie od umowy, } \\
\text { umowa zawierana na odległość, kon- } \\
\text { sument, dziedziczenie, umowa rachun- } \\
\text { ku bankowego, zgoda rodzica na za- } \\
\text { warcie umowy przez małoletniego, } \\
\text { określenie limitu wypłat i przelewów, } \\
\text { umowa pożyczki, rozporządzanie za- } \\
\text { robkiem małoletniego, naruszenie dóbr } \\
\text { osobistych, zadośćuczynienie, regula- } \\
\text { min świadczenia usług telekomunika- } \\
\text { cyjnych, podpisanie umowy bez jej } \\
\text { czytania. }\end{array}$ \\
\hline $\begin{array}{l}\text { Zespół Prawa } \\
\text { Gospo- } \\
\text { darczego i } \\
\text { Rynku Pracy }\end{array}$ & $\begin{array}{l}\text { - informator wiedzy } \\
\text { prawniczej }\end{array}$ & $\begin{array}{l}\text { 1. Zatrudnienie na podstawie Kodeksu } \\
\text { pracy: rodzaje umów o pracę, szcze- } \\
\text { gólne zasady zatrudniania młodocia- } \\
\text { nych pracowników, podstawowe } \\
\text { obowiązki pracodawcy w zakresie } \\
\text { dokumentowania faktu zatrudnienia, } \\
\text { zgłoszenia pracownika do ubezpie- } \\
\text { czenia społecznego i odprowadzania } \\
\text { składek na to ubezpieczenie oraz do- } \\
\text { niosłość tych obowiązków dla przy- } \\
\text { szłej sytuacji pracownika, wydanie } \\
\text { świadectwa pracy po ustaniu stosun- } \\
\text { ku pracy, podstawowe uprawnienia } \\
\text { pracownika, podnoszenie kwalifikacji } \\
\text { zawodowych pracowników, podsta- } \\
\text { wowe obowiązki pracownika, zakaz } \\
\text { konkurencji, formy ustania stosunku } \\
\text { pracy; }\end{array}$ \\
\hline
\end{tabular}




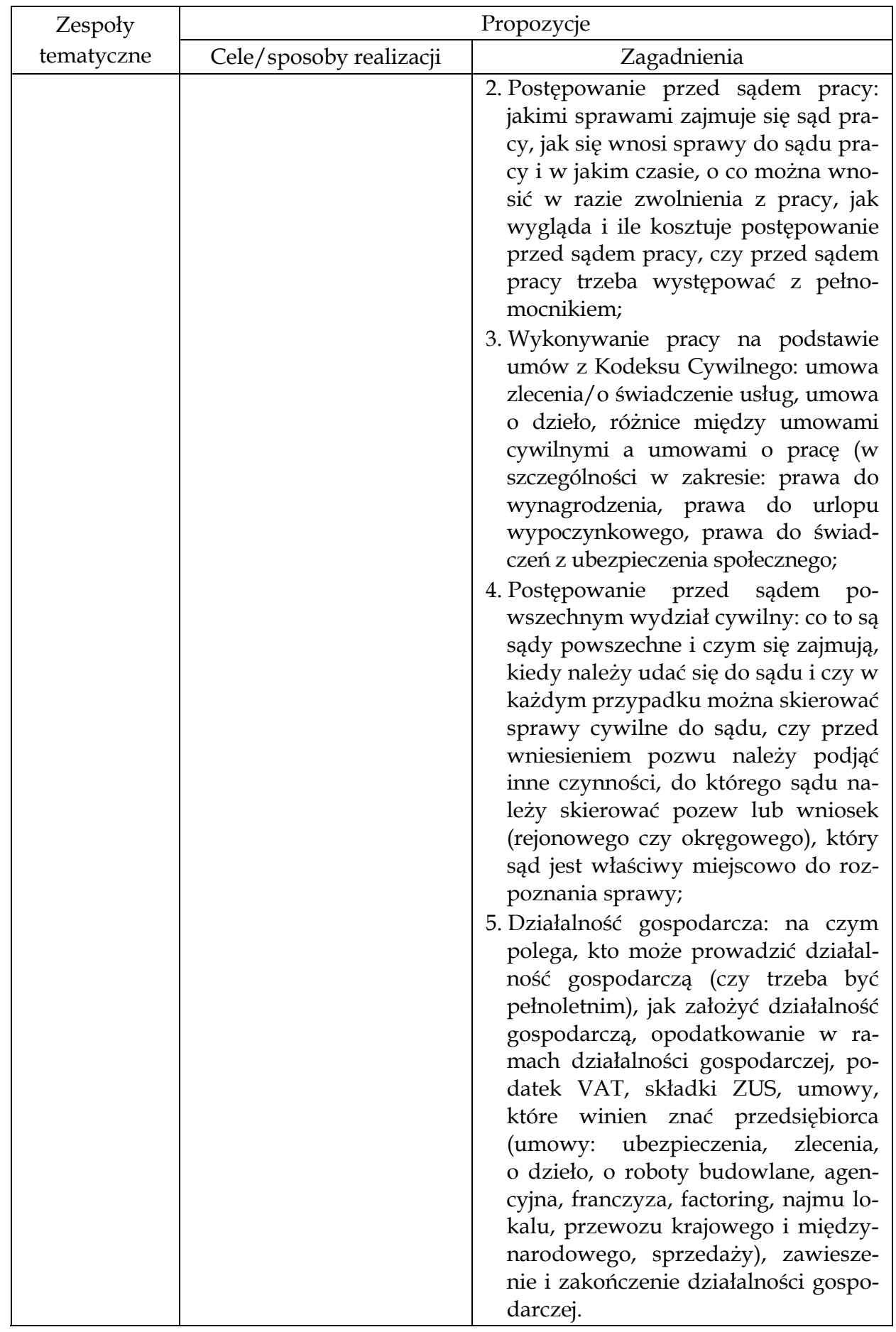




\begin{tabular}{|c|c|c|}
\hline \multirow{2}{*}{$\begin{array}{c}\text { Zespoły } \\
\text { tematyczne }\end{array}$} & \multicolumn{2}{|r|}{ Propozycje } \\
\hline & Cele/sposoby realizacji & Zagadnienia \\
\hline & & $\begin{array}{l}\text { 6. Prowadzenie działalności w ramach } \\
\text { wybranych spółek. } \\
\text { 7. Krajowy Rejestr Sądowy i Centralna } \\
\text { Ewidencja i Centralna Ewidencja } \\
\text { i Informacja o Działalności Gospodar- } \\
\text { czej, biura informacji gospodarczej. } \\
\text { 8. Przedsiębiorca przed sądem - sądy } \\
\text { gospodarcze i sądy pracy. } \\
\text { 9. Znaczenie ugody i mediacji w postę- } \\
\text { powaniu cywilnym oraz mediacji } \\
\text { przedsądowej. } \\
\text { 10. Praca za granicą: wakacyjna praca } \\
\text { dla młodzieży (gdzie uzyskać infor- } \\
\text { macje o pracodawcach, ubezpiecze- } \\
\text { nie, pomoc prawna w przypadku za- } \\
\text { istnienia przestępstwa związanego } \\
\text { z podjętą pracą), praca dla osób do- } \\
\text { rosłych (migracja młodych Polaków } \\
\text { w poszukiwaniu pracy, nostryfikacja } \\
\text { dyplomów, ubezpieczenie, rejestra- } \\
\text { cja, kwestie podatkowe). } \\
\text { 11. Postępowanie egzekucyjne: co to jest } \\
\text { egzekucja, czym się zajmuje komor- } \\
\text { nik, właściwość rzeczowa i miejsco- } \\
\text { wa organów egzekucyjnych i moż- } \\
\text { liwość wyboru komornika, co to jest } \\
\text { tytuł egzekucyjny, klauzula wyko- } \\
\text { nalności i tytułu wykonawczego, } \\
\text { sposób wykonania wyroku zasądza- } \\
\text { jącego świadczenie, składniki mająt- } \\
\text { ku, które komornik może zajać, } \\
\text { skarga na czynności i bezczynności } \\
\text { komornika, obowiązki komornika } \\
\text { jako płatnika podatku dochodowego } \\
\text { od osób fizycznych w sprawach pra- } \\
\text { cowniczych, płatnika podatku od } \\
\text { towarów i usług przy sprzedaży ru- } \\
\text { chomości i nieruchomości dłużnika. }\end{array}$ \\
\hline $\begin{array}{l}\text { Zespół Prawa } \\
\text { Rodzinnego }\end{array}$ & $\begin{array}{l}\text { - zajęcia dodatkowe pro- } \\
\text { wadzone przez prawni- } \\
\text { ków, rozszerzenie kom- } \\
\text { petencyjne struktur } \\
\text { istniejących m.in. psy- } \\
\text { cholog szkolny, mediacja } \\
\text { jako alternatywa rozwią- }\end{array}$ & $\begin{array}{l}\text { 1. Definicje i poziomy zdolności do } \\
\text { czynności prawnych; przedstawienie } \\
\text { katalogu najczęściej zawieranych } \\
\text { umów w drobnych bieżących spra- } \\
\text { wach życia codziennego z porusze- } \\
\text { niem kwestii rażącego pokrzywdze- } \\
\text { nia małoletniego. }\end{array}$ \\
\hline
\end{tabular}




\begin{tabular}{|c|c|c|}
\hline \multirow{2}{*}{$\begin{array}{c}\text { Zespoły } \\
\text { tematyczne }\end{array}$} & \multicolumn{2}{|r|}{ Propozycje } \\
\hline & Cele/sposoby realizacji & Zagadnienia \\
\hline & $\begin{array}{l}\text { zywania konfliktów } \\
\text { i sporów, akcja informa- } \\
\text { cyjna przy wykorzysta- } \\
\text { niu nowych nośników: } \\
\text { Internet, komiksy, bro- } \\
\text { szury, kazusy, symulacje } \\
\text { zachowań (przesłucha- } \\
\text { nie, rozprawa itd.), mi- } \\
\text { niporadniki, rozbudo- } \\
\text { wanie legitymacji szkol- } \\
\text { nej o część: Twoje pod- } \\
\text { stawowe prawa (instru- } \\
\text { kcja działania w nagłych } \\
\text { sytuacjach prawnych) }\end{array}$ & 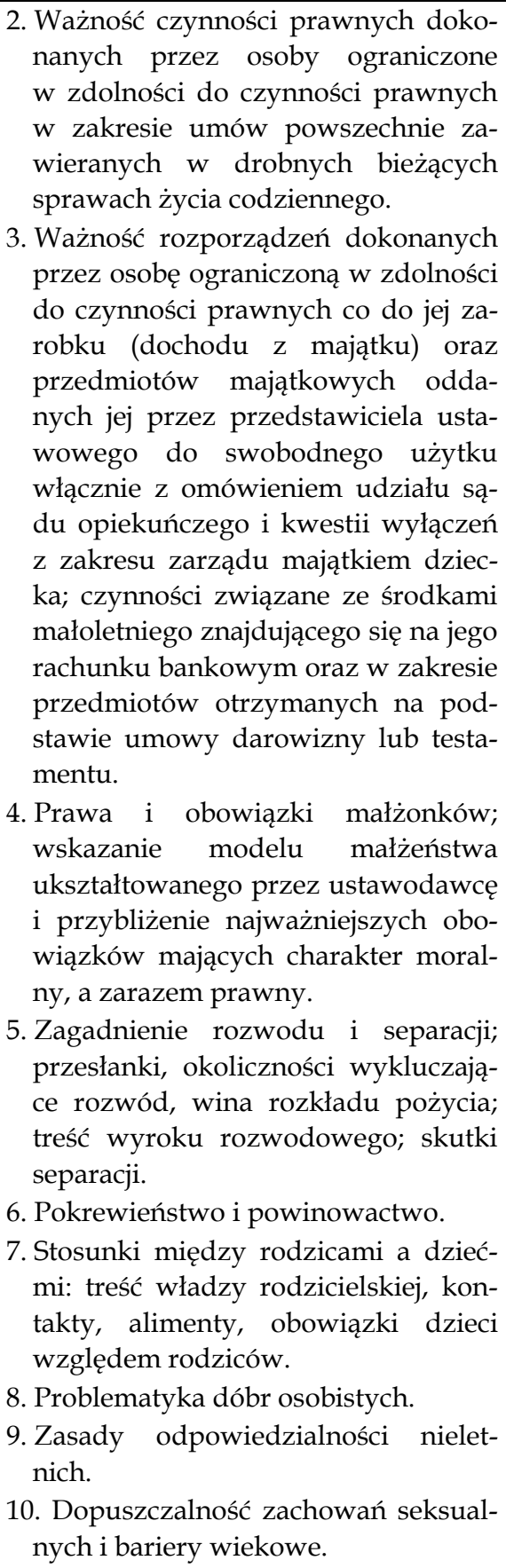 \\
\hline
\end{tabular}




\begin{tabular}{|c|c|c|}
\hline \multirow{2}{*}{$\begin{array}{c}\text { Zespoły } \\
\text { tematyczne }\end{array}$} & \multicolumn{2}{|r|}{ Propozycje } \\
\hline & Cele/sposoby realizacji & Zagadnienia \\
\hline $\begin{array}{l}\text { Zespół Prawa } \\
\text { Administra- } \\
\text { cyjnego }\end{array}$ & $\begin{array}{l}\text { - zagadnienia do porusze- } \\
\text { nia w ramach obowiąz- } \\
\text { kowej podstawy pro- } \\
\text { gramowej }\end{array}$ & $\begin{array}{l}\text { 1. Pouczenie jako obligatoryjny element } \\
\text { każdej decyzji (postanowienia). Skutki } \\
\text { (nie)zastosowania się do pouczenia. } \\
\text { 2. Składanie odwołań, zażaleń, skarg } \\
\text { "za pośrednictwem” innego organu. } \\
\text { 3. Doręczenie zastępcze oraz jego skut- } \\
\text { ki. Fikcja doręczenia oraz jej skutki. } \\
\text { 4. Pełnomocnik w postępowaniu admi- } \\
\text { nistracyjnym. } \\
\text { 5. Komunikacja elektroniczna. }\end{array}$ \\
\hline
\end{tabular}

Źródło: www.poznan.sa.gov.pl.

Konstruktywna analiza zaproponowanych treści programowych może przyczynić się do wdrożenia programu edukacji prawnej pod warunkiem, że szkoły zechcą zeń skorzystać, mając równocześnie na względzie ministerialną (skądinąd słuszną sugestię) wykorzystywania wszelkich dostępnych kanałów informacji ${ }^{29}$. Gotowość w tym względzie deklarują prawnicy, rozwijając $\mathrm{w}$ ostatnich latach szereg inicjatyw (np. organizowany przez OIRP $\mathrm{w}$ Poznaniu cykl bezpłatnych, profesjonalnie stworzonych, lekcji poświęconych tematyce prawnej w ramach projektu „PrawoTeczka - lekcje prawa dla młodzieży"30, konkursy dotyczące znajomości prawa dla uczniów, lekcje prawa prowadzone przez praktyków, bezpłatne szkolenia dla nauczycieli). Pozostaje jednak pytanie podstawowe: czy polska szkoła jest gotowa uczyć prawa? Obecnie wydaje się, że nie, ale braki kompetencyjne można z czasem uzupełnić, a niedobory programowe stopniowo wypełniać, stwarzając treściowe podwaliny dla nowego przedmiotu, realizowanego $\mathrm{w}$ przyszłości przez nauczycieli, merytorycznie do tego przygotowanych. $Z$ pewnością, nie należy szkoły pozostawić bez wsparcia, z ministerialnym zestawem celów i treści kształcenia jako receptą na edukacyjny sukces.

Mając powyższe na uwadze podkreślmy, że pozycja jednostki we współczesnym społeczeństwie jest $\mathrm{w}$ znacznym stopniu zdeterminowana za przyczyną ustanowienia gwarancji dla jej praw i wolności, a także wyznaczenia jej powinności i obowiązków ${ }^{31}$. Za instrument sprawczy tego stanu rzeczy

${ }^{29} \mathrm{~W}$ zalecanych warunkach i sposobach realizacji reformy programowej można przeczytać, iż w związku z kształtowaniem u uczniów pożądanych postaw obywatelskich szkoła powinna umożliwiać uczniom dostęp do różnych źródeł informacji i różnych punktów widzenia, patrz: Tom 4, Edukacja historyczna i obywatelska, www.bc.ore.edu.pl, s. 110.

${ }^{30}$ www.prawoteka.pl.

31 T. Woś, J. Stelmach (red.), Wiedza o społeczeństwie, Warszawa 2003, s. 25. 
należy uznać prawo, które poprzez kształtowanie przestrzeni normatywnej wywołuje określone zmiany w życiu społecznym oraz edukację, która tożsame efekty uzyskuje $\mathrm{w}$ drodze procesów wychowawczo-edukacyjnych. Umiejętne połączenie tych dyscyplin $\mathrm{w}$ szkole pozwoli bardziej realnie wdrażać programowe założenia kształtowania przedstawicieli społeczeństwa obywatelskiego (świadomy obywatel to aktywny obywatel), niejako naturalnie uruchomi na wczesnym etapie mechanizm prewencyjny (znajdujący swoje uzasadnienie $\mathrm{w}$ łacińskiej paremii: ignorantia iuris nocet, a $\mathrm{w}$ dalszej perspektywie - poprzez uodpornienie wyborców na wszelkie odmiany populizmu politycznego - da szansę na osiągnięcie przez RP kanonów demokratycznego państwa prawa.

\section{BIBLIOGRAFIA}

§2.1. Rozporządzenia Ministra Edukacji Narodowej z 12 marca 2009 r. w sprawie szczegółowych kwalifikacji wymaganych od nauczycieli oraz określenia szkół i wypadków, w których można zatrudnić nauczycieli niemających wyższego wykształcenia lub ukończonego zakładu kształcenia nauczycieli (DzU nr 50, poz. 400 ze zm.)

Art. 3 Ustawy o systemie oświaty z 07.09.1991 r., DzU nr 95, poz. 425 z późn. zm.

Komunikat CBOS: Kontakty z prawem, ocena instytucji prawnych i poczucie bezpieczeństwa Polaków (nr BS/42/2008).

Komunikat CBOS: O przestrzeganiu prawa i funkcjonowaniu wymiaru sprawiedliwości w Polsce (nr BS/5/2013).

Machura-Szczęsna J., Sędzia i kaganek oświaty, Na Wokandzie, 2012, 1, 11.

Marciniak Z., O potrzebie reformy programowej ksztatcenia ogólnego, [w:] Tom 4, Edukacja historyczna i obywatelska w szkole podstawowej, gimnazjum i liceum, Biblioteka Cyfrowa ORE, www.bc.ore.edu.pl.

Niewiadomski Z. (red.), Prawo administracyjne, Warszawa 2011.

Ochendowski E., Prawo administracyjne. Część ogólna, Toruń 2009.

Pilich M., Ustawa o systemie oświaty. Komentarz, Warszawa 2012.

Podstawa programowa z komentarzem, tom 4: Edukacja historyczna $i$ obywatelska w szkole podstawowej, gimnazjum i liceum. Historia i społeczeństwo, historia, wiedza o społeczeństwie, podstawy przedsiębiorczości, ekonomia w praktyce, wychowanie do życia w rodzinie, etyka, filozofia, www.bc.ore.edu.pl.

Preambuła do Ustawy o systemie oświaty z 07.09.1991 r., DzU nr 95, poz. 425 z późn. zm.

Redelbach A., Wstęp do prawoznawstwa, Torun 2002.

Rozporządzenie MEN z 27 sierpnia 2012 r. w sprawie podstawy programowej wychowania przedszkolnego oraz kształcenia ogólnego w poszczególnych typach szkół DzU z 2012 r., poz. 977.

Sądy to moje życie - wywiad Krystiana Markiewicza i Bartłomieja Przymusińskiego z sędzią Stanisławem Dąbrowskim, Pierwszym Prezesem Sądu Najwyższego, Iustitia, 2012, 1 . 
Schmidt D., Koncepcja niemieckiej pedagogiki prawa w ujecciu Sigrun von Hasseln, [w:] Prawo $i$ ład spoteczny. Integralnokulturowa analiza zagadnienia racjonalności, red. J. UtratMilecki, Warszawa 2011.

Woś T., Stelmach J. (red.), Wiedza o spoteczeństwie, Warszawa 2003.

Zimmermann J., Prawo administracyjne, Kraków 2006.

http://www.cbos.pl/PL/publikacje/raporty.php

www.perspektywy.pl/index.php?option=com_content\&task=view\&id=2537.

www.poznan.sa.gov.pl.

www.prawoteka.pl. 